\title{
Review
}

\section{Current Management of Patients with Severe von Willebrand Disease Type 3: A 2012 Update}

\author{
Augusto B. Federici ${ }^{a}$ Paula James $^{\mathrm{b}}$ \\ ${ }^{a}$ Hematology and Transfusion Medicine, L. SACCO University Hospital and Department of Clinical Sciences \\ and Community Health, University of Milan, Milan, Italy; ${ }^{\text {b }}$ Department of Medicine, Queen's University, \\ Kingston, Ont., Canada
}

\section{Key Words}

Von Willebrand disease type $3 \cdot$ Von Willebrand factor concentrates $\cdot$ Desmopressin $\cdot$ Alloantibodies

\begin{abstract}
Von Willebrand disease type 3 (VWD3) is the most severe form of this bleeding disorder due to the almost complete deficiency of von Willebrand factor (VWF). VWD3 is inherited as an autosomal recessive trait. While heterozygous carriers exhibit mild or no bleeding symptoms, most patients with VWD3, which is characterized by undetectable levels of VWF antigen (VWF:Ag) and reduced concentrations ( $<20 \mathrm{IU} / \mathrm{dl}$ ) of factor VIII (FVIII), show severe bleeding symptoms. Although the incidence of VWD3 is rare, the condition is of considerable interest because of its severe clinical presentation, the need for replacement therapy and the risk of alloantibodies following infusion of plasma-derived VWF concentrates. This review, based on clinical experience, provides an update on the clinical, laboratory and molecular markers of VWD3 that can be useful for determining the optimal therapeutic approach in these patients.

Copyright $\odot 2012$ S. Karger AG, Basel
\end{abstract}

\section{Introduction}

Von Willebrand disease (VWD) is a bleeding disorder resulting from inherited defects in von Willebrand factor (VWF) $[1,2]$. VWF is a plasma glycoprotein that mediates platelet adhesion to injured blood vessel sites and promotes platelet aggregation $[3,4]$. In addition, VWF binds factor VIII (FVIII), an essential cofactor of factor IXa, and protects it from degradation by plasma proteases, thus prolonging its half-life $[3,4]$. VWF is present in the form of multimers of up to $20,000 \mathrm{kDa}$ composed of a different number of disulfide-linked dimers, with the largest multimers having the highest hemostatic potential [5, 6]. Type 1 VWD (VWD1) results from a partial quantitative deficiency of VWF and accounts for $60-70 \%$ of VWD cases; it is inherited mostly as an autosomal dominant trait [4]. The qualitative defects of VWF are classified according to phenotype in 4 different types, $2 \mathrm{~A}, 2 \mathrm{~B}, 2 \mathrm{M}$ and $2 \mathrm{~N}$ [2]. Type $3 \mathrm{VWD}$ (VWD3) is due to an almost complete deficiency of VWF [7]. VWD3 is inherited as an autosomal recessive trait, with heterozygous carriers being asymptomatic or exhibiting mild bleeding $[1,8,9]$. The disease is characterized by undetectable levels of VWF antigen (VWF:Ag) and reduced concentrations of FVIII (<20 IU/dl) [1, 4]. The first case of VWD3 was de-

\section{KARGER \\ Fax +4161306 1234 \\ E-Mail karger@karger.ch}

www.karger.com
2012 S. Karger AG, Basel

$0001-5792 / 12 / 1282-0088 \$ 38.00 / 0$

Accessible online at:

www.karger.com/aha
Augusto B. Federici, MD

Hematology and Transfusion Medicine, L. SACCO University Hospital and Department of Clinical Sciences and Community Health, University of Milan IT-20122 Milan (Italy)

Tel. +39025031 9895, E-Mail augusto.federici@unimi.it 
scribed by Erik von Willebrand in Finland in 1926, and, after similar cases were reported during the 1950s, Inga Nilsson et al. [10] confirmed in 1957 that the same disease was found in Sweden. VWD3 is a rare disorder, affecting $0.1-5.3$ people per million [11-13]. The incidence in Europe and North America is comparable (1.51 and 1.38 per million, respectively), whereas the incidence amongst the Arab community is higher (5.3 per million).

\section{Clinical Markers of VWD3}

Patients with VWD3 usually meet all 3 main criteria required for the diagnosis of VWD: a history of bleeding episodes since childhood, reduced plasma VWF and autosomal recessive inheritance [14]. Clinical markers are very important and include a negative history of bleeding in parents in most families because of the autosomal recessive inheritance and moderate to severe bleeding episodes in most cases. However, some patients with VWD3 may have relatively mild symptoms, despite the VWF deficiency, probably due to residual levels of VWF and/or individual FVIII levels $[15,16]$. Because VWF deficiency results in the rapid degradation and depletion of FVIII, in VWD3 both primary and secondary hemostasis is affected. The main clinical manifestations are disproportionate mucocutaneous bleeding, severe menorrhagia and hemophilia-like symptoms, such as muscle hematomas and joint bleeding $[1,14,17]$. The most common sites of bleeding are the nose, gingiva and gastrointestinal tract [18]. In VWD3 patients with very low FVIII levels, postoperative bleeding is often observed [19]. Patients with joint bleeding are at risk of long-term joint damage, which can limit patient mobility and independence [20].

Few reports have described VWD3 symptoms in detail after Silwer's first report [18]. The prevalence of VWD3 symptoms has been investigated in Iranian [17] and Italian [19] populations of patients in particular. The most common symptoms in these patients were epistaxis (74-77\% of cases), menorrhagia (32-69\% of women) and bleeding following tooth extractions (53-70\% of cases). Hematoma and joint bleeding occurred in $31-52 \%$ and in $37-42 \%$ of patients, respectively $[17,19]$.

A bleeding severity score can be useful to predict the risk of bleeding in VWD including VWD3. The severity of each bleeding symptom is graded from 0 (no/trivial bleeding) to 4 [blood transfusion/replacement therapy/ desmopressin (DDAVP)], and an additional grade, -1 , assigned to clinical situations associated with a high bleeding risk (e.g. tooth extraction, surgery or delivery) in which bleeding did not occur, despite no antihemorrhagic prophylaxis [21]. A bleeding severity score for 12 bleeding symptoms was calculated for 154 families in which VWD1 occurred (affected and unaffected members) and for 200 healthy individuals [21]. The value of this tool has also been evaluated in patients with other VWD types, such as VWD2B [22] and VWD1 with increased clearance [23]. This approach might also be useful in VWD3, and it will be introduced in the prospective study entitled 'Type 3 von Willebrand Disease International Registries and Inhibitor Prospective Study (3WINTERS-IPS)' organized on behalf of the European Group on VWD3 and approved by the VWF subcommittee of the International Society on Thrombosis and Haemostasis Scientific and Standardization Committee and the European Association of Hemophilia and Allied Disorders.

\section{Laboratory Markers of VWD3}

VWD3 can be more easily diagnosed than other VWD types due to the severity of the VWF and FVIII deficiency. Whereas in VWD1, VWF is commonly at the lower end of the normal range (with approximately $95 \%$ of plasma VWF levels between 50 and $200 \mathrm{IU} / \mathrm{dl}[8,24])$, in VWD3, VWF is virtually absent. Furthermore, the FVIII level is usually 2-20 IU/dl in patients with VWD3 (FVIII normal range: 50-150 IU/dl) [1]. In addition, abnormal hemostasis test results can suggest the presence of VWD3. The hallmark of VWD3 is a markedly prolonged bleeding time, sometimes $>35 \mathrm{~min}$, which is due to the extremely low levels of VWF in both the plasma and platelets. Partial thromboplastin time is also prolonged due to the low concentrations of FVIII, although platelet count is normal [25]. In patients with very low VWF and FVIII levels who have a prolonged bleeding time and partial thromboplastin time, plasma levels of VWF:Ag should be always measured to confirm the diagnosis of VWD3 and to distinguish this VWD type from patients affected by severe forms of VWD1; concentrations below $1 \mathrm{IU} / \mathrm{dl}$ are usually considered 'undetectable' even if they are measurable by currently-used high-sensitivity methods (e.g. ELISA) [19]. The presence of discrete amounts of VWF:Ag circulating in VWD3 patients is still under investigation; the role of platelet VWF in VWD3 should be analyzed further. In addition, in the plasma of some patients with VWD3, VWF might be found predominantly in the form of monomers, and multimers cannot be detected by agarose gel electrophoresis [19]. 
Due to a lack of detectable VWF:Ag, traditional VWF activity measurements for ristocetin cofactor (VWF:RCo) and collagen-binding assay (VWF:CB) are also undetectable. However, in most laboratories, these assays are less sensitive than the VWF ELISA, and so results may be reported as $<5$ or $<10 \mathrm{IU} / \mathrm{dl}$.

\section{Molecular Markers of VWD}

Molecular biology techniques have identified several VWF gene defects that can cause VWD3, including large gene deletions, nonsense mutations, small deletions/insertions or frameshift mutations, splice-site mutations and missense mutations.

Complete VWF gene deletions are considered rare. A complete homozygous VWF gene deletion was identified in 2 patients with VWD3 [26] and in 4 family members with severe VWD [27]. The latter study showed that seven asymptomatic individuals from 2 families were heterozygous for the complete deletion [27]. A complete deletion (Delta253k) was identified in homozygous, compound heterozygous and heterozygous members of 2 nonconsanguineous families from Germany and Italy [28], confirming previous reports of complete deletion in families in these countries $[16,29]$. Seven partial homozygous VWF gene deletions including exons 1-3, 6-16, $42,33-38,22-43,23-52$ and $17-18$ have been described [30-35]. Of these, a deletion of exons 1-3 resulting from an Alu-mediated recombination event was found to be the most common defect in Hungarian patients with VWD3 [32].

Most VWF defects are caused by single nucleotide substitutions or small deletions/insertions. More than 30 different nonsense mutations have been identified by DNA sequencing and various screening techniques, the majority of which cause a frame shift resulting in a premature stop codon [36].

Over 15 splice-site mutations have been reported, half of which affect the guanine at position +1 or -1 [37]. However, only 2 of these mutations have been confirmed at the mRNA level [16, 38].

Missense mutations have also been reported in patients with VWD3, yet it is not clear how these mutations could cause the low VWF level in plasma. Some of the approximately 30 missense mutations found so far may have a common mechanism of impairing VWF function, such as preventing VWF dimerization [37].

\section{Treatment and Prevention of Bleeding in VWD3}

The aim of treatment for VWD is to correct the defect in platelet adhesion that is due to low/defective VWF and the abnormal coagulation that is due to low levels of FVIII. There are 2 main treatments available for VWD: stimulation of the release of endogenous VWF from endothelial cells with desmopressin and supplementation with plasma-derived VWF/FVIII-containing concentrates.

By definition, patients with VWD3 are considered unresponsive to desmopressin as successful treatment depends upon endogenous synthesis of functional VWF, which is impaired in these patients [39-41]. Therefore this therapy is not recommended, although a small group of patients (reported to have VWD3) responded to desmopressin treatment with an increase in VWF and FVIII [15]. It would be interesting if these patients could be enrolled into the current prospective study on VWD3 (3WINTERS-IPS) [42] in order to be able to evaluate their clinical, laboratory and molecular markers to confirm VWD3 diagnosis.

\section{VWF/FVIII Concentrates}

The first-line treatment for VWD3 is replacement therapy with plasma-derived VWF/FVIII concentrates. These can be given to stop bleeding episodes when they occur (treatment on demand), to prevent bleeding during surgery (prophylaxis for surgery) or to prevent recurrent bleeding at specific sites (secondary long-term prophylaxis). The minimum requirements for plasma-derived VWF/FVIII concentrates for the management of VWD are: (1) they must contain enough biologically active VWF to correct the primary hemostasis defect and to stabilize the endogenous FVIII molecule (the latter objective can be achieved independently of the content of exogenous FVIII), (2) they should be treated by virucidal methods, (3) before clinical use, their pharmacokinetics and efficacy should be tested in retrospective or prospective clinical trials in relatively large numbers of VWD patients. Only a few of the many VWF/FVIII concentrates available on the market meet these requirements (table 1).

Alphanate $^{\circledR}$ (Grifols Biologicals Inc., Los Angeles, Calif., USA) effectively stopped active bleeding and provided adequate hemostasis for surgical procedures in a multicenter, prospective study in 81 patients with VWD, 32 of whom had VWD3 [43]. The plasma concentrations of VWF:RCo and FVIII increased to normal levels $15 \mathrm{~min}$ 
Table 1. Characteristics of available VWF/FVIII concentrates

A Concentrates with published VWF activity assessed in a relatively large number of VWD subjects

\begin{tabular}{|c|c|c|c|c|c|c|c|}
\hline Fanhdi & $\begin{array}{l}\text { Federici et al. } 2010 \text { [46] } \\
\text { Hernandez-Navarro et al. } 2008 \text { [91] } \\
\text { Bello et al. } 2007 \text { [45] } \\
\text { Federici et al. } 2002[44]\end{array}$ & $\begin{array}{l}\text { precipitation, } \\
\text { heparin ligand CT }\end{array}$ & $\begin{array}{l}\text { SD; } \\
\text { dry heat }\end{array}$ & 0.6 & 1.6 & SP, IT & Grifols (SP) \\
\hline Haemate- $\mathrm{P}^{\mathrm{b}}$ & $\begin{array}{l}\text { Halimeh et al. 2011 [81] } \\
\text { Gill et al. 2011 [52] } \\
\text { Federici et al. 2007 [41] } \\
\text { Coppola et al. } 2006 \text { [92] } \\
\text { Thompson et al. } 2004 \text { [51] } \\
\text { Michiels et al. } 2004 \text { [93] } \\
\text { Gill et al. 2003 [50] } \\
\text { Franchini et al. 2003 [49] } \\
\text { Lillicrap et al. } 2002 \text { [48] } \\
\text { Lubetsky et al. } 1999 \text { [94] }\end{array}$ & $\begin{array}{l}\text { polyelectrolyte } \\
\text { precipitations }\end{array}$ & $\begin{array}{l}\text { Pasteur- } \\
\text { ization }\end{array}$ & 0.8 & 2.5 & $\begin{array}{l}\text { ASIA, } \\
\text { EUR, USA }\end{array}$ & CSL Behring \\
\hline Wilate & $\begin{array}{l}\text { Berntorp et al. } 2009[60] \\
\text { Halimeh et al. } 2011[81] \\
\text { Kessler et al. } 2011[95] \\
\text { Windyga et al. } 2011[61]\end{array}$ & $\begin{array}{l}\text { affinity CT, } \\
\text { size exclusion }\end{array}$ & $\begin{array}{l}\text { SD; } \\
\text { dry heat }\end{array}$ & 0.7 & 0.8 & GE & Octapharma \\
\hline Wilfactin & $\begin{array}{l}\text { Borel-Derlon et al. } 2007 \text { [59] } \\
\text { Goudemand et al. } 2005 \text { [58] }\end{array}$ & $\begin{array}{l}\text { ion-exchange, } \\
\text { affinity CTs }\end{array}$ & $\begin{array}{l}\text { SD; NF; } \\
\text { dry heat }\end{array}$ & 0.7 & 60 & $\mathrm{FR}$ & LFB (Lille) \\
\hline
\end{tabular}

B Concentrates with limited VWF activity and/or published studies in a relatively small number of VWD subjects

\begin{tabular}{llllllll}
\hline Emoclot & - & ion-exchange CT & $\begin{array}{l}\text { SD; } \\
\text { dry heat }\end{array}$ & 0.5 & 1.2 & BR, IT & Kedrion \\
\hline Immunate & $\begin{array}{l}\text { Auerswald et al. 2002 [96] } \\
\text { Ver Elst et al. 2004 [97] }\end{array}$ & ion-exchange CT & $\begin{array}{l}\text { SD; } \\
\text { vapor heat }\end{array}$ & 0.2 & 0.2 & EUR & Baxter \\
\hline Innobrand & - & ion-exchange CT & SD & 0.7 & 2.5 & FR & LFB (Lille) \\
\hline Koate DVI & Viswabandy et al. 2008 [98] & $\begin{array}{l}\text { precipitations, } \\
\text { size exclusion }\end{array}$ & $\begin{array}{l}\text { SD; } \\
\text { dry heat }\end{array}$ & 0.5 & 1.2 & USA & Talecris \\
\hline $8 Y$ & $\begin{array}{l}\text { Lubetsky et al. 2002 [99] } \\
\text { Cumming et al. 1990 [100] }\end{array}$ & precipitations & dry heat & 0.3 & 0.8 & UK & BioProducts \\
\hline
\end{tabular}

Adapted from [37] and reproduced with permission from John Wiley, Copyright 2011. AU = Australia; BR = Brazil; CT = chromatography; EUR = Europe; FR = France; GE = Germany; IT = Italy; NF = nanofiltration; $\mathrm{SD}=$ solvent-detergent $\left(\mathrm{t}-\mathrm{N}-\mathrm{butyl}-\mathrm{PO}_{4}\right.$ with polysorbate, Tween, or otoxynol, Triton); SP = Spain.

${ }^{a}$ Ratio of ristocetin cofactor activity (VWF:RCo) to VWF:Ag or FVIII activity expressed as IU/dl (or \% of a normal pool).

${ }^{\mathrm{b}}$ Humate-P in USA. 
after infusion, with a corresponding decrease in bleeding time from $>30$ to 10.5 min. Bleeding episodes in VWD3 patients were controlled with an average of 3 infusions administered at a median interval of $16 \mathrm{~h}$. Bleeding due to surgical procedures was effectively controlled with a median of 3 infusions at a median interval of $24 \mathrm{~h}$. Alphanate tolerability was good, with $14 \%$ of patients experiencing nonserious adverse events (AEs) possibly related to study medication.

Results of a retrospective study in 22 patients with VWD, 6 of whom had VWD3, showed that Fanhdi ${ }^{\circledR}$ (Grifols, Barcelona, Spain) was effective in controlling bleeding episodes and preventing excessive bleeding in surgical procedures [44]. No AEs were reported. In 2 open, noncontrolled, multicenter studies in VWD patients unresponsive to DDAVP, Fanhdi showed excellent or good efficacy in controlling both spontaneous and surgery-related bleeding episodes [45]. Two nonserious AEs were reported (phlebitis, considered possibly related and seroma, considered doubtfully related to study medication).

In one of the largest studies available on Fanhdi and Alphanate, (Fanhdi and Alphanate Italian Retrospective Study on Willebrand disease, FAIReSt.Will), 120 patients of all VWD types (10 VWD3, 19 VWD2A, 25 VWD2B, 10 VWD2M and 56 desmopressin-unresponsive VWD1) were analyzed retrospectively. The patient population had a median bleeding severity score of 8 ( $>5$ indicates moderate and severe cases). Clinical responses to the products were good-to-excellent in $97 \%$ of bleeding episodes and in $99 \%$ of surgical procedures. A partial response was observed in gastrointestinal bleeding, one of the most complicated situations in VWD, possibly because other causes of bleeding were involved [46].

Haemate $\mathrm{P}^{\circledR} /$ Humate- $\mathrm{P}^{\circledR}$ (CSL Behring, Marburg, Germany) is a preparation with a very high content of high molecular weight VWF multimers (HMWM) and a high ratio of VWF to FVIII content (VWF:FVIII; table 1). The efficacy and tolerability of Haemate P/Humate-P have been well documented in 3 retrospective and 3 prospective studies. In a retrospective evaluation in $97 \mathrm{Ca}-$ nadian patients, 28 of whom had VWD3, the efficacy of Haemate P/Humate-P was rated as excellent in $99 \%$ of surgeries, in $97 \%$ of bleeding episodes and in all prophylactic treatments $[47,48]$. Tolerability was good, with related AEs being nonserious and of mild or moderate intensity (chills, phlebitis, vasodilatation, paresthesia, pruritus, rash and urticaria). Another retrospective study confirmed the efficacy and good tolerability of Haemate $\mathrm{P} /$ Humate-P in 26 patients with VWD1 or VWD2A un- dergoing surgical interventions and showed that the mean daily doses and duration of treatment were higher for major than for minor surgery (mean 39.3 VWF:RCo $\mathrm{IU} / \mathrm{kg}$, mean 10.3 infusions vs. $28.7 \mathrm{VWF}:$ RCo IU/kg, mean 2.9 infusions, respectively) [49]. No related AEs or thrombotic episodes were reported. The largest retrospective study enrolled 100 Italian patients, 37 of whom had VWD3 [41]. In 95\% of the patients treated for bleeding events ( $n=59)$ and in $97 \%$ of those treated for surgical procedures $(n=56)$, responses were rated as excellent or good. Tolerability was good, with no serious AEs or thrombotic episodes. Two prospective, open-label, nonrandomized studies conducted in the USA assessed the clinical efficacy and safety of this preparation in acute bleeding events [50] and in urgent surgical situations [51]. The first study reported excellent or good efficacy in $98 \%$ of the 53 bleeding events, 27 of which were in patients with VWD3 (median loading dose 67.0 VWF:RCo IU/kg and median daily maintenance dose 74.0 VWF:RCo IU/ $\mathrm{kg}$ ) [50]. One related AE was reported (mild allergic reaction) and 2 treatment episodes were associated with serious AEs unrelated to the study treatment. The other study evaluated 39 patients with VWD, 8 of whom had VWD3, and reported excellent or good efficacy in all evaluated treatment events (median loading dose 82.3 VWF:RCo IU/kg and median daily maintenance dose 52.8 VWF:RCo IU/kg) [51]. Eight related AEs (2 events of paresthesia, allergic reaction, vasodilatation, peripheral edema, extremity pain, pseudo-thrombocytopenia and pruritus) and 4 unrelated serious AEs were reported. Another prospective, open-label, multinational study in 35 patients undergoing surgery, 13 of whom had VWD3, showed effective hemostasis in $91 \%$ of patients immediately after surgery [52]. Treatment-related AEs (headache, itching, nausea and dizziness) were generally mild and of short duration. Dosing of Haemate P/Humate-P for bleeding prophylaxis in surgery was determined by measuring the individual preoperative in vivo recovery of VWF in a prospective open-label multicenter study [53]. Of the 29 patients in this study, 9 were diagnosed with VWD3. The median recovery of VWF:RCo was $1.9 \mathrm{IU} / \mathrm{dl}$ per IU/kg infused and no significant differences related to VWD type were observed [53]. Based on these results, a median dose of $62.4 \mathrm{VWF}$ :RCo IU/kg was used for prophylaxis in surgery, with efficacy rated as excellent or good in $96.3 \%$ of patients on the day of surgery and in all patients on the next day.

Biostate $^{\circledR}$ (CSL Ltd, Melbourne, Australia) is a preparation with a high VWF/FVIII ratio (table 1). With respect to FVIII:C and VWF markers, Biostate showed 
pharmacokinetic behavior similar to that of AHF (highpurity, CSL), a VWF/FVIII concentrate previously licensed in Australia for the treatment of hemophilia A [54]. In a retrospective study of $43 \mathrm{VWD}$ patients undergoing surgical procedures, 5 of whom had VWD3, Biostate showed an excellent $(78 \%)$ or good $(22 \%)$ hemostatic activity [55] in all of the 58 evaluated surgical procedures. No AEs related to Biostate administration were observed. In a prospective trial of 23 patients with VWD, 7 with VWD3, the hemostatic efficacy of Biostate was rated as excellent or good in all patients for all major and minor surgery events, for long-term prophylaxis, and for 4 of the 6 assessable nonsurgical bleeding events [56]. More recently, the results of a retrospective trial assessing the efficacy and safety of Biostate were reported for 43 children with VWD. In the VWD3 subgroup $(\mathrm{n}=7)$, the hemostatic efficacy of Biostate was rated as excellent or good for $94 \%$ of all surgical and nonsurgical events. Biostate was well tolerated, with 1 case of nausea reported, possibly related to the study drug [57]. The current global clinical development program, SWIFT (Studies with von Willebrand factor/Factor VIII), is evaluating the pharmacokinetics, efficacy and safety of Biostate. It includes centers in Europe, Latin America and South America and consists of 6 clinical trials, 2 of which SWIFT-VWD in adults (NCT00941616) and SWIFTLYVWD in children (NCT01213446) - involve patients with VWD who may continue in the extension study - SWIFTVWD-xt (NCT01224808) - to investigate the long-term safety and efficacy of Biostate.

Wilfactin ${ }^{\circledR}$ (LFB, Les Ulis, France) is a VWF concentrate depleted of FVIII. Two crossover, randomized, pharmacokinetic studies in 25 patients with VWD, 14 of whom had VWD3, showed that bleeding time was reduced in $71-86 \%$ of patients [58]. The only difference between Wilfactin and the VWF/FVIII concentrates was the 6-hour delay in FVIII increase with Wilfactin. Thus, for the treatment of acute bleeding, particularly in patients with VWD3 who had very low FVIII levels, supplementation with exogenous FVIII was recommended [58]. Wilfactin has been used successfully for many years in the treatment of VWD patients in hemophilia centers in France. Its efficacy and safety were investigated by pooling the results of 2 comparable prospective studies conducted in 5 European and 12 French centers. Of a total of 139 spontaneous bleeding episodes treated, 53 (38\%) required a concomitant FVIII dose. Outcome was excellent or good in $89 \%$ of the episodes. Forty-four patients underwent 108 surgical or invasive procedures. Outcome was excellent or good in 95 of the scheduled procedures (only VWF was used) and 13 emergency procedures (a priming FVIII dose was coadministered with the first VWF infusion). There were no thrombotic complications and none of the VWD3 patients developed anti-VWF or anti-FVIII inhibitors [59].

Data on Wilate ${ }^{\circledR}$ (Octapharma, Lachen, Switzerland), a preparation with a low VWF:FVIII ratio (table 1), are available from a recent clinical review that included $4 \mathrm{Eu}-$ ropean prospective, open-label, noncontrolled, nonrandomized, multicenter phase II or phase III clinical trials. Its efficacy and safety in spontaneous or posttraumatic bleeding was demonstrated in 44 patients with VWD (1,095 bleeding episodes), 24 of whom had VWD3 [60]. Tolerability was rated as very good or good in $99 \%$ of the 5,310 infusions, and no thrombotic events were reported; 13 related AEs in 5 patients were documented. The efficacy in the perioperative management of bleeding (57 surgical procedures in 32 patients, 19 of whom had VWD3) was rated as excellent or good in $96 \%$ of the interventions, with tolerability rated as very good or good in all interventions: according to the data of this study there was no accumulation of FVIII after repeated injections [61].

The recommended doses of VWF/FVIII concentrates depend on the product used and the clinical situation of the patient (table 2). The VWF:FVIII ratio is important to ensure that VWF is raised to an appropriate level, whilst maintaining a concentration of FVIII that will not induce thrombosis $[62,63]$. Data comparing VWF/FVIII factor concentrates with a high (Haemate $\mathrm{P}$ ) or low (Wilate) VWF:FVIII ratio in a rabbit model showed that the cumulative exposure to FVIII was $84 \%$ higher in animals treated with Wilate compared to those treated with Haemate P [64]. These results suggested that elevated FVIII levels could be avoided through the use of VWF/ FVIII concentrates with higher VWF:FVIII ratios [64]. Factor concentrates vary also in their HMWM content (table 1). Because large VWF multimers are essential for platelet adhesion to sites of vascular injury and only the largest multimers are hemostatically active [4], a higher HMWM content is expected to be favorable for clinical efficacy.

Despite the differences in purity, VWF/FVIII content and virucidal techniques used, there is no evidence from retrospective or prospective clinical studies that the 6 VWF-containing concentrates (Alphanate, Biostate, Fanhdi, Haemate P, Wilate and Wilfactin), discussed above and shown in table 1, differ with regard to efficacy and safety, because, to date, no head-to-head clinical study has been carried out. Therefore, all of these VWF 
Table 2. Commonly recommended doses of VWF/FVIII concentrates in the treatment of VWD3

\begin{tabular}{|c|c|c|c|}
\hline Indication & $\begin{array}{l}\text { Dose }^{\mathrm{a}} \\
\text { (VWF:RCo units) }\end{array}$ & $\begin{array}{l}\text { Frequency of infusions } \\
\text { (treatment duration) }\end{array}$ & Target VWF:RCo and FVIII levels \\
\hline $\begin{array}{l}\text { Spontaneous or } \\
\text { traumatic bleeding }\end{array}$ & $25 \mathrm{IU} / \mathrm{kg}$ & $\begin{array}{l}\text { daily infusions } \\
\text { (2-4 days) }\end{array}$ & maintain trough VWF:RCo and FVIII level $>50 \%$ of normal level \\
\hline Tooth extraction & $20-40 \mathrm{IU} / \mathrm{kg}$ & single infusion & achieve trough VWF:RCo and FVIII level $>50 \%$ of normal level \\
\hline $\begin{array}{l}\text { Major surgery } \\
\text { Loading } \\
\text { Maintenance }\end{array}$ & $\begin{array}{l}40-60 \mathrm{IU} / \mathrm{kg} \\
20-40 \mathrm{IU} / \mathrm{kg}\end{array}$ & $\begin{array}{l}\text { every } 8-24 \mathrm{~h} \\
(7-14 \text { days })\end{array}$ & maintain trough VWF:RCo and FVIII level $>50 \%$ of normal level \\
\hline
\end{tabular}

concentrates can be considered to be effective and well tolerated in the treatment or prevention of bleeding in VWD patients when the appropriate dosage (20-60 U/kg, see table 2) of VWF:RCo is administered [37].

\section{Adjuvant Treatments}

Antifibrinolytic agents, such as tranexamic acid and $\varepsilon$-aminocaproic acid, may be used in combination with plasma-derived VWF/FVIII concentrates to promote hemostasis and wound healing in dental extractions, tonsillectomy, menorrhagia and mucosal hemorrhage, but not in muscle hematomas or joint bleeding [1]. Platelet transfusions may be required in patients experiencing excessive and recurrent bleeding (e.g. gastrointestinal) despite treatment with VWF/FVIII concentrates and have been shown to be effective in some, if not all, patients [65-67].

\section{Complications/Difficulties Associated with Treatment of VWD3}

In rare cases (approximately $7.5-9.5 \%$ [68]), patients with VWD3 may develop anti-VWF alloantibodies. Most patients developing anti-VWF alloantibodies have a complete VWF gene deletion and thus a complete VWF deficiency $[26,27,69]$; however, not all of those with a complete deletion develop the antibodies [29]. All reported anti-VWF alloantibodies belong to the IgG class, yet their titer and specificity differs between patients $[69,70]$.
Their presence not only renders VWF/FVIII replacement therapy ineffective, due to their interaction with the VWF domains critical for the therapy [69-73], but also introduces the risk of life-threatening anaphylactic reactions developing [70]. In fact, an increased level of circulating immune complexes is often observed after infusion of VWF/FVIII concentrates in patients with anti-VWF alloantibodies, which, in turn, may lead to classic complement pathway activation $[70,71,73]$. Patients who do not respond to VWF/FVIII replacement therapy with an increase in the plasma levels of both factors should be tested for the presence of anti-VWF alloantibodies. In such cases, recombinant factor VIIa (rFVIIa) and recombinant FVIII (rFVIII) products, which are devoid of VWF, may be used [70, 74-76]. As with VWF/FVIII concentrates, care should be taken to maintain the FVIII level below 150-200 IU/dl to reduce the risk of thrombosis [62].

\section{Secondary Long-Term Prophylaxis}

Patients who experience frequent and severe bleeding episodes should be considered for regular prophylaxis with VWF/FVIII factor concentrates. For example, in patients with frequent bleeding in joints, long-term prophylaxis should be commenced before the development of joint disease, as is recommended for most bleeding disorders $[77,78]$. The most common indications for long-term prophylaxis include joint bleeding, nose/mouth bleeding, menorrhagia and gastrointestinal bleeding $[79,80]$. 
The overall percentage of VWD patients treated with prophylaxis is low (reported as $1.6 \%$ in a study of 6,208 patients [77]), with the use of prophylaxis being more common in VWD3 than VWD1 or VWD2 (23.9\% versus 0.2 or $1.8 \%$, respectively, in a study of 5,343 patients [78]). The largest study of secondary long-term prophylaxis in VWD was conducted in 35 patients with severe VWD (28 of whom had VWD3) in Sweden [79]. The results showed that $63 \%$ of adult patients had been treated for more than 10 years with a resulting marked decrease in the number of joint bleeds. A recent study in 32 patients with VWD (13 of whom had VWD3) receiving prophylaxis for a median duration of 3 years reported a significant reduction in monthly bleeding frequency (from 3 to $0.07, \mathrm{p}<0.001$ ) and the bleeding score (from 3 to $0, p<0.001$ ) over the 12-month observation period [79]. Preliminary results of an ongoing study in Germany in 24 patients with VWD3 showed reduction in bleeding events during periods of prophylaxis [81].

So far, the experience available does not allow the estimation and comparison of the costs for prophylaxis with the costs for treatment on demand [78]. The reported patient benefits of long-term prophylaxis include a decreased number of bleeding episodes, decreased severity of bleeds, prevention of arthropathy, an improved quality of life and allowing patients to lead a more normal life [82, 83]. In a survey in 34 federally funded Hemophilia Treatment Centers in the USA, $73 \%$ of respondents considered prophylaxis very/extremely helpful [20].

Not all patients may require long-term prophylaxis. The VWD Prophylaxis Network (VWD PN; http://www. vwd-prophy.com) has initiated a study to evaluate the benefits of long-term treatment. The aim is to determine the responsiveness to prophylaxis in patients with clinical manifestations of joint, gastrointestinal and/or nasal/oral bleeding, or menorrhagia, and the dose and intervals of treatment required to control bleeding episodes. In the prospective phase of the study, patients are treated with increasing doses of VWF/FVIII concentrate depending on the clinical events; patients will be observed for a follow-up period of 1 year. The VWD PN International Prophylaxis (VIP) nonrandomized dose-escalation study aims to identify people with VWD who may benefit from prophylaxis, to evaluate the effects of prophylaxis on bleeding frequency and to establish the optimal treatment regimens for joint bleeding, gastrointestinal bleeding, epistaxis and menorrhagia. Patients will receive prophylaxis with VWF/FVIII concentrate at doses increasing in 3 steps until bleeding is controlled, with initial doses being individually determined; patients will be fol- lowed up to 1 year. The VIP study also includes 2 retrospective studies to evaluate the efficacy of prophylaxis on the frequency of bleeding episodes in patients who are already receiving prophylaxis at the study centers, and to capture the natural history of gastrointestinal bleeding in patients with VWD.

The cost-effectiveness of prophylaxis regimens versus on-demand therapy is currently under investigation in another prospective study (PRO.WILL) organized in Italy, Spain and the UK [84].

\section{Future Treatments}

The currently available treatments with plasma-derived VWF/FVIII concentrates are suitable for all patients with VWD and mandatory for those with VWD3. Recombinant products are being developed and tested in clinical trials. Recombinant VWF has been characterized in vitro and in animal models, with promising results, and is currently undergoing clinical trials concerning treatment for VWD [85]. The interim results of a phase I pharmacokinetic study conducted in a cohort of $31 \mathrm{pa}-$ tients with VWD3 or VWD1 have recently been reported [86]. Recombinant interleukin 11 (IL-11) induces a gradual and sustained increase in VWF and FVIII levels by a mechanism different from that of desmopressin, as shown in a phase II, prospective, open-label, escalating-dose trial [87]. Therefore, IL-11 may be used in combination with desmopressin to overcome tachyphylaxis, or for the treatment of patients who are refractory to desmopressin. A recent phase II study in 7 women with mild VWD and refractory menorrhagia showed that recombinant IL-11 reduced the severity and duration of bleeding in 71 and $85 \%$ of patients, respectively [88]. Potential long-term or lifelong correction of VWF deficiency may be possible by delivery of the VWF protein by gene therapy [89]. As VWD results from a defect in a single gene, and because VWF is secreted in the circulation, which obviates the need for specific targeting, VWD is a good candidate for gene therapy [89]. However, with large proteins such as VWF, the technical difficulties are not negligible.

\section{Conclusion}

The treatment of VWD3 aims at correcting platelet adhesion and at restoring normal coagulation. The recommended first-line treatment is replacement therapy with plasma-derived VWF/FVIII concentrates, as pa- 
tients with VWD3 do not respond to desmopressin. An important issue in VWD3 therapy is maintaining adequate levels of FVIII by using repeated infusions of exogenous VWF contained in VWF/FVIII concentrates. However, the circulating levels of FVIII should always be monitored after frequent infusions in order to avoid thrombotic events. Antifibrinolytic agents and platelet transfusions may be used concomitantly with VWF/ FVIII concentrates as adjuvant therapy. Prophylaxis should be considered at least in some VWD3 patients, particularly those who experience frequent bleeding in joints or recurrent gastrointestinal bleeding. The patient benefits and cost-effectiveness of long-term prophylaxis need to be evaluated in prospective studies. Individual tailoring of the therapy to a patient's clinical situation and response to treatment is currently the best choice.

\section{Acknowledgments}

Editorial assistance in the preparation of this manuscript was provided by Fishawack Communications and was funded by CSL Behring.

\section{Disclosure Statement}

Dr. Federici has participated in medical advisory boards and/ or data monitor committees proposed by Baxter, CSL Behring, Grifols, Kedrion, LFB and Octapharma and he has also received honoraria for educational events.

Dr. James has received honoraria for educational events and research funding from Bayer, Baxter and CSL Behring.

\section{References}

1 Eikenboom JC: Congenital von Willebrand disease type 3: clinical manifestations, pathophysiology and molecular biology. Best Pract Res Clin Haematol 2001;14:365-379.

-2 Sadler JE, Budde U, Eikenboom JC, Favaloro EJ, Hill FG, Holmberg L, Ingerslev J, Lee CA, Lillicrap D, Mannucci PM, Mazurier C, Meyer D, Nichols WL, Nishino M, Peake IR, Rodeghiero F, Schneppenheim R, Ruggeri ZM, Srivastava A, Montgomery RR, Federici $\mathrm{AB}$ : Update on the pathophysiology and classification of von Willebrand disease: a report of the subcommittee on von Willebrand factor. J Thromb Haemost 2006;4:2103-2114.

-3 Ruggeri ZM: Structure of von Willebrand factor and its function in platelet adhesion and thrombus formation. Best Pract Res Clin Haematol 2001;14:257-279.

4 Furlan M: Von Willebrand factor: molecular size and functional activity. Ann Hematol 1996;72:341-348.

5 Dent JA, Galbusera M, Ruggeri ZM: Heterogeneity of plasma von Willebrand factor multimers resulting from proteolysis of the constituent subunit. J Clin Invest 1991;88: 774-782.

6 Ruggeri ZM, Zimmerman TS: Variant von Willebrand's disease: characterization of two subtypes by analysis of multimeric composition of factor VIII/von Willebrand factor in plasma and platelets. J Clin Invest 1980;65:1318-1325.

7 Sadler JE: A revised classification of von Willebrand disease. For the subcommittee on von Willebrand factor of the scientific and standardization committee of the International Society on Thrombosis and Haemostasis. Thromb Haemost 1994;71:520-525.
8 Mannucci PM, Lattuada A, Castaman G, Lombardi R, Colibretti ML, Ciavarella N, Rodeghiero F: Heterogeneous phenotypes of platelet and plasma von Willebrand factor in obligatory heterozygotes for severe von Willebrand disease. Blood 1989;74:2433-2436.

-9 Castaman G, Rodeghiero F, Tosetto A, Cappelletti A, Baudo F, Eikenboom JC, Federici $A B$, Lethagen S, Linari S, Lusher J, Nishino M, Petrini P, Srivastava A, Ungerstedt JS: Hemorrhagic symptoms and bleeding risk in obligatory carriers of type 3 von Willebrand disease: an international, multicenter study. J Thromb Haemost 2006;4:2164-2169.

10 Nilsson IM: Commentary to Erik von Willebrand's original paper from 1926 'Hereditär pseudohemofili'. Haemophilia 1999; 5:220-221.

11 Berliner SA, Seligsohn U, Zivelin A, Zwang E, Sofferman G: A relatively high frequency of severe (type III) von Willebrand's disease in Israel. Br J Haematol 1986;62:535-543.

12 Mannucci PM, Bloom AL, Larrieu MJ, Nilsson IM, West RR: Atherosclerosis and von Willebrand factor. I. Prevalence of severe von Willebrand's disease in Western Europe and Israel. Br J Haematol 1984;57:163-169.

13 Weiss HJ, Ball AP, Mannucci PM: Incidence of severe von Willebrand's disease. N Engl J Med 1982;307:127.

14 Federici AB, Mannucci PM: Management of inherited von Willebrand disease in 2007. Ann Med 2007;39:346-358.

15 Castaman G, Lattuada A, Mannucci PM, Rodeghiero F: Factor VIII:C increases after desmopressin in a subgroup of patients with autosomal recessive severe von Willebrand disease. Br J Haematol 1995;89:147-151.
16 Eikenboom JC, Castaman G, Vos HL, Bertina RM, Rodeghiero F: Characterization of the genetic defects in recessive type 1 and type 3 von Willebrand disease patients of Italian origin. Thromb Haemost 1998;79:709-717.

17 Lak M, Peyvandi F, Mannucci PM: Clinical manifestations and complications of childbirth and replacement therapy in 385 Iranian patients with type 3 von Willebrand disease. Br J Haematol 2000;111:1236-1239.

18 Silwer J: Von Willebrand disease in Sweden. Acta Paediatr Scand Suppl 1973;238:1-159.

19 Federici AB, Castaman G, Mannucci PM: Guidelines for the diagnosis and management of von Willebrand disease in Italy. Haemophilia 2002;8:607-621.

20 Sumner M, Williams J: Type 3 von Willebrand disease: assessment of complications and approaches to treatment - results of a patient and Hemophilia Treatment Center Survey in the United States. Haemophilia 2004;10:360-366.

21 Tosetto A, Rodeghiero F, Castaman G, Goodeve A, Federici AB, Batlle J, Meyer D, Fressinaud E, Mazurier C, Goudemand J, Eikenboom J, Schneppenheim R, Budde U, Ingerslev J, Vorlova Z, Habart D, Holmberg L, Lethagen S, Pasi J, Hill F, Peake I: A quantitative analysis of bleeding symptoms in type 1 von Willebrand disease: results from a multicenter European study (MCMDM-1 VWD). J Thromb Haemost 2006;4:766-773.

22 Federici AB, Mannucci PM, Castaman G, Baronciani L, Bucciarelli P, Canciani MT, Pecci A, Lenting PJ, De Groot PG: Clinical and molecular predictors of thrombocytopenia and risk of bleeding in patients with von Willebrand disease type 2B: a cohort study of 67 patients. Blood 2009;113:526-534. 
-23 Castaman G, Tosetto A, Federici AB, Rodeghiero F: Bleeding tendency and efficacy of anti-haemorrhagic treatments in patients with type 1 von Willebrand disease and increased von Willebrand factor clearance. Thromb Haemost 2011;105:647-654.

-24 Gill JC, Endres-Brooks J, Bauer PJ, Marks WJ Jr, Montgomery RR: The effect of ABO blood group on the diagnosis of von Willebrand disease. Blood 1987;69:1691-1695.

- 25 Weiss HJ, Pietu G, Rabinowitz R, Girma JP, Rogers J, Meyer D: Heterogeneous abnormalities in the multimeric structure, antigenic properties, and plasma-platelet content of factor VIII/von Willebrand factor in subtypes of classic (type I) and variant (type IIA) von Willebrand's disease. J Lab Clin Med 1983;101:411-425.

-26 Shelton-Inloes BB, Chehab FF, Mannucci PM, Federici AB, Sadler JE: Gene deletions correlate with the development of alloantibodies in von Willebrand disease. J Clin Invest 1987;79:1459-1465.

-27 Ngo KY, Glotz VT, Koziol JA, Lynch DC, Gitschier J, Ranieri P, Ciavarella N, Ruggeri ZM, Zimmerman TS: Homozygous and heterozygous deletions of the von Willebrand factor gene in patients and carriers of severe von Willebrand disease. Proc Natl Acad Sci USA 1988;85:2753-2757.

-28 Schneppenheim R, Castaman G, Federici $A B$, Kreuz W, Marschalek R, Oldenburg J, Oyen F, Budde U: A common 253-kb deletion involving VWF and TMEM16B in German and Italian patients with severe von Willebrand disease type 3. J Thromb Haemost 2007;5:722-728.

-29 Schneppenheim R, Krey S, Bergmann F, Bock D, Budde U, Lange M, Linde R, Mittler U, Meili E, Mertes G, Olek K, Plendl H, Simeoni E: Genetic heterogeneity of severe von Willebrand disease type III in the German population. Hum Genet 1994;94:640652.

-30 Baronciani L, Cozzi G, Canciani MT, Peyvandi F, Srivastava A, Federici AB, Mannucci PM: Molecular characterization of a multiethnic group of 21 patients with type 3 von Willebrand disease. Thromb Haemost 2000; 84:536-540.

-31 Mancuso DJ, Tuley EA, Castillo R, de Bosch N, Mannucci PM, Sadler JE: Characterization of partial gene deletions in type III von Willebrand disease with alloantibody inhibitors. Thromb Haemost 1994;72:180185.

32 Mohl A, Marschalek R, Masszi T, Nagy E, Obser T, Oyen F, Sallai K, Bodo I, Schneppenheim R: An Alu-mediated novel large deletion is the most frequent cause of type 3 von Willebrand disease in Hungary. J Thromb Haemost 2008;6:1729-1735.
33 Peake IR, Liddell MB, Moodie P, Standen G, Mancuso DJ, Tuley EA, Westfield LA, Sorace JM, Sadler JE, Verweij CL, Bloom AL: Severe type III von Willebrand's disease caused by deletion of exon 42 of the von Willebrand factor gene: family studies that identify carriers of the condition and a compound heterozygous individual. Blood 1990;75:654-661.

- 34 Xie F, Wang X, Cooper DN, Chuzhanova N, Fang Y, Cai X, Wang Z, Wang H: A novel Alu-mediated 61-kb deletion of the von Willebrand factor (VWF) gene whose breakpoints co-locate with putative matrix attachment regions. Blood Cells Mol Dis 2006;36: 385-391.

35 Abuzenadah A, Gursel T, Ingerslev J: Multinational analysis of the von Willebrand factor gene in 27 families from Turkey with von Willebrand disease. Thromb Haemost 1999; 82:283.

36 ISTH-SSC VWF Online Database: http:// vwf.group.shef.ac.uk/ (accessed December 2011).

37 Baronciani L, Federici A, Eikenboom J: Clinical, laboratory, and molecular markers of type 3 von Willebrand disease; in Federici A, Lee CA, Berntorp E, Lillicrap D, Montgomery RR (eds): Von Willebrand Disease: Basic and Clinical Aspects. Oxford, Wiley-Blackwell, 2011.

38 Mertes G, Ludwig M, Finkelnburg B, Krawczak M, Schwaab R, Brackmann HH, Olek K: A G+3-to-T donor splice site mutation leads to skipping of exon 50 in von Willebrand factor mRNA. Genomics 1994;24:190-191.

- 39 Castaman G, Federici AB, Rodeghiero F, Mannucci PM: Von Willebrand's disease in the year 2003: towards the complete identification of gene defects for correct diagnosis and treatment. Haematologica 2003;88:94-108.

40 Cattaneo M, Simoni L, Gringeri A, Mannucci PM: Patients with severe von Willebrand disease are insensitive to the releasing effect of DDAVP: evidence that the DDAVP-induced increase in plasma factor VIII is not secondary to the increase in plasma von Willebrand factor. Br J Haematol 1994;86:333337.

41 Federici AB, Castaman G, Franchini M, Morfini M, Zanon E, Coppola A, Tagliaferri A, Boeri E, Mazzucconi MG, Rossetti G, Mannucci PM: Clinical use of Haemate P in inherited von Willebrand's disease: a cohort study on 100 Italian patients. Haematologica 2007;92:944-951.

42 Federici AB, Mannucci PM, Steering Committee of the Type 3 von Willebrand International Registries Inhibitor Prospective Study (3WINTERS-IPS): http://www.vwd-3winters-ips.com (accessed December 2011).

43 Mannucci PM, Chediak J, Hanna W, Byrnes J, Ledford M, Ewenstein BM, Retzios AD, Kapelan BA, Schwartz RS, Kessler C: Treatment of von Willebrand disease with a highpurity factor VIII/von Willebrand factor concentrate: a prospective, multicenter study. Blood 2002;99:450-456.
44 Federici AB, Baudo F, Caracciolo C, Mancuso G, Mazzucconi MG, Musso R, Schinco PC, Targhetta R, Mannuccio Mannucci P: Clinical efficacy of highly purified, doubly virus-inactivated factor VIII/von Willebrand factor concentrate (Fanhdi) in the treatment of von Willebrand disease: a retrospective clinical study. Haemophilia 2002;8: 761-767.

45 Bello IF, Yuste VJ, Molina MQ, Navarro FH: Fanhdi, efficacy and safety in von Willebrand's disease: prospective international study results. Haemophilia 2007;13(suppl 5):25-32.

46 Federici AB, Barillari G, Zanon E, Mazzucconi MG, Musso R, Targhetta R, Mannucci PM: Efficacy and safety of highly purified, doubly virus-inactivated VWF/FVIII concentrates in inherited von Willebrand's disease: results of an Italian cohort study on 120 patients characterized by bleeding severity score. Haemophilia 2010;16:101-110.

-47 Dobrkovska A, Krzensk U, Chediak JR: Pharmacokinetics, efficacy and safety of $\mathrm{Hu}$ mate-P in von Willebrand disease. Haemophilia 1998;4(suppl 3):33-39.

48 Lillicrap D, Poon MC, Walker I, Xie F, Schwartz BA: Efficacy and safety of the factor VIII/von Willebrand factor concentrate, haemate-P/humate-P: ristocetin cofactor unit dosing in patients with von Willebrand disease. Thromb Haemost 2002;87:224-230.

49 Franchini M, Rossetti G, Tagliaferri A, Pattacini C, Pozzoli D, Lippi G, Manzato F, Bertuzzo D, Gandini G: Efficacy and safety of factor VIII/von Willebrand's factor concentrate (Haemate-P) in preventing bleeding during surgery or invasive procedures in patients with von Willebrand disease. Haematologica 2003;88:1279-1283.

50 Gill JC, Ewenstein BM, Thompson AR, Mueller-Velten G, Schwartz BA: Successful treatment of urgent bleeding in von Willebrand disease with factor VIII/VWF concentrate (Humate-P): use of the ristocetin cofactor assay (VWF:RCo) to measure potency and to guide therapy. Haemophilia 2003;9:688-695.

51 Thompson AR, Gill JC, Ewenstein BM, Mueller-Velten G, Schwartz BA: Successful treatment for patients with von Willebrand disease undergoing urgent surgery using factor VIII/VWF concentrate (Humate-P). Haemophilia 2004;10:42-51.

52 Gill JC, Shapiro A, Valentino LA, Bernstein J, Friedman C, Nichols WL, Manco-Johnson M: von Willebrand factor/factor VIII concentrate (Humate-P) for management of elective surgery in adults and children with von Willebrand disease. Haemophilia 2011; 17:895-905. 
53 Lethagen S, Kyrle PA, Castaman G, Haertel S, Mannucci PM: von Willebrand factor/factor VIII concentrate (Haemate P) dosing based on pharmacokinetics: a prospective multicenter trial in elective surgery. J Thromb Haemost 2007;5:1420-1430.

-54 Favaloro EJ, Lloyd J, Rowell J, Baker R, Rickard K, Kershaw G, Street A, Scarff K, Barrese G, Maher D, McLachlan AJ: Comparison of the pharmacokinetics of two von Willebrand factor concentrates [Biostate and AHF (High Purity)] in people with von Willebrand disorder. A randomised cross-over, multi-centre study. Thromb Haemost 2007;97:922930.

- 55 Shortt J, Dunkley S, Rickard K, Baker R, Street A: Efficacy and safety of a high purity, double virus inactivated factor VIII/von Willebrand factor concentrate (Biostate) in patients with von Willebrand disorder requiring invasive or surgical procedures. Haemophilia 2007;13:144-148.

-56 Dunkley S, Baker RI, Pidcock M, Price J, Seldon M, Smith M, Street A, Maher D, Barrese G, Stone C, Lloyd J: Clinical efficacy and safety of the factor VIII/von Willebrand factor concentrate BIOSTATE in patients with von Willebrand's disease: a prospective multi-centre study. Haemophilia 2010;16: 615-624.

57 Howman R, Barnes C, Curtin J, Price J, Robertson J, Russell S, Seldon M, Suppiah R, Teague L, Barrese G: The clinical efficacy and safety of the FVIII/VWF concentrate, BIOSTATE $^{\circledR}$, in children with von Willebrand disorder: a multi-centre retrospective review. Haemophilia 2011;17:463-469.

- 58 Goudemand J, Scharrer I, Berntorp E, Lee CA, Borel-Derlon A, Stieltjes N, Caron C, Scherrmann JM, Bridey F, Tellier Z, Federici AB, Mannucci PM: Pharmacokinetic studies on Wilfactin, a von Willebrand factor concentrate with a low factor VIII content treated with three virus-inactivation/removal methods. J Thromb Haemost 2005;3:22192227.

-59 Borel-Derlon A, Federici AB, Roussel-Robert V, Goudemand J, Lee CA, Scharrer I, Rothschild C, Berntorp E, Henriet C, Tellier Z, Bridey F, Mannucci PM: Treatment of severe von Willebrand disease with a high-purity von Willebrand factor concentrate (Wilfactin): a prospective study of 50 patients. J Thromb Haemost 2007;5:1115-1124.

60 Berntorp E, Windyga J: Treatment and prevention of acute bleedings in von Willebrand disease - efficacy and safety of Wilate, a new generation von Willebrand factor/factor VIII concentrate. Haemophilia 2009; 15: 122-130.

-61 Windyga J, von Depka-Prondzinski M: Efficacy and safety of a new generation von Willebrand factor/factor VIII concentrate (Wilate ${ }^{\circledR}$ ) in the management of perioperative haemostasis in von Willebrand disease patients undergoing surgery. Thromb Haemost 2011;105:1072-1079.
62 Federici AB: The safety of plasma-derived von Willebrand/factor VIII concentrates in the management of inherited von Willebrand disease. Expert Opin Drug Saf 2009;8: 203-210.

63 Nichols WL, Hultin MB, James AH, MancoJohnson MJ, Montgomery RR, Ortel TL, Rick ME, Sadler JE, Weinstein M, Yawn BP: von Willebrand disease (VWD): evidencebased diagnosis and management guidelines, the National Heart, Lung, and Blood Institute (NHLBI) Expert Panel report (USA). Haemophilia 2008; 14:171-232.

64 Raquet E, Stockschlader M, Dickneite G: Repeated infusions of VWF/FVIII concentrate: impact of VWF:FVIII ratio on FVIII trough and peak levels in a rabbit model. Haemophilia 2011;17:808-814.

65 Boda Z, Pfliegler G, Harsfalvi J, Rak K: Treatment of the severe bleeding episode in type III von Willebrand's disease by simultaneous administration of cryoprecipitate and platelet concentrate. Blood Coagul Fibrinolysis 1991;2:775-777.

66 Castillo R, Escolar G, Monteagudo J, AznarSalatti J, Reverter JC, Ordinas A: Hemostasis in patients with severe von Willebrand disease improves after normal platelet transfusion and normalizes with further correction of the plasma defect. Transfusion 1997;37: 785-790.

67 Castillo R, Monteagudo J, Escolar G, Ordinas A, Magallon M, Martin Villar J: Hemostatic effect of normal platelet transfusion in severe von Willebrand disease patients. Blood 1991;77:1901-1905.

68 Mannucci PM, Federici AB: Antibodies to von Willebrand factor in von Willebrand disease. Adv Exp Med Biol 1995;386:87-92.

69 Tout H, Obert B, Houllier A, Fressinaud E, Rothschild C, Meyer D, Girma JP: Mapping and functional studies of two alloantibodies developed in patients with type 3 von Willebrand disease. Thromb Haemost 2000;83: 274-281.

-70 Bergamaschini L, Mannucci PM, Federici AB, Coppola R, Guzzoni S, Agostoni A: Posttransfusion anaphylactic reactions in a patient with severe von Willebrand disease: role of complement and alloantibodies to von Willebrand factor. J Lab Clin Med 1995; 125:348-355.

71 Mannucci PM, Cattaneo M: Alloantibodies in congenital von Willebrand's disease. Ric Clin Lab 1991;21:119-125.

72 Mannucci PM, Ruggeri ZM, Ciavarella N, Kazatchkine MD, Mowbray JF: Precipitating antibodies to factor VIII/von Willebrand factor in von Willebrand's disease: effects on replacement therapy. Blood 1981;57:25-31.

73 Mannucci PM, Tamaro G, Narchi G, Candotti G, Federici A, Altieri D, Tedesco F: Lifethreatening reaction to factor VIII concentrate in a patient with severe von Willebrand disease and alloantibodies to von Willebrand factor. Eur J Haematol 1987;39:467470 .
74 Boyer-Neumann C, Dreyfus M, Wolf M, Veyradier A, Meyer D: Multi-therapeutic approach to manage delivery in an alloimmunized patient with type 3 von Willebrand disease. J Thromb Haemost 2003;1:190-192.

75 Ciavarella N, Schiavoni M, Valenzano E, Mangini F, Inchingolo F: Use of recombinant factor VIIa (NovoSeven) in the treatment of two patients with type III von Willebrand's disease and an inhibitor against von Willebrand factor. Haemostasis 1996;26(suppl 1):150-154

76 Grossmann RE, Geisen U, Schwender S, Keller F: Continuous infusion of recombinant factor VIIa (NovoSeven) in the treatment of a patient with type III von Willebrand's disease and alloantibodies against von Willebrand factor. Thromb Haemost 2000;83:633-634.

77 Berntorp E, Astermark J, Bjorkman S, Blanchette VS, Fischer K, Giangrande PL, Gringeri A, Ljung RC, Manco-Johnson MJ, Morfini M, Kilcoyne RF, Petrini P, Rodriguez-Merchan EC, Schramm W, Shapiro A, van den Berg HM, Hart C: Consensus perspectives on prophylactic therapy for haemophilia: summary statement. Haemophilia 2003;9(suppl 1):1-4.

78 Oldenburg J: Prophylaxis in bleeding disorders. Thromb Res 2011;127(suppl 1):S14-S17.

79 Berntorp E: Prophylaxis and treatment of bleeding complications in von Willebrand disease type 3. Semin Thromb Hemost 2006; 32:621-625.

80 Mannucci PM: Treatment of von Willebrand's Disease. N Engl J Med 2004;351: 683-694.

81 Halimeh S, Krumpel A, Rott H, Bogdanova N, Budde U, Manner D, Faeser B, Mesters R, Nowak-Gottl U: Long-term secondary prophylaxis in children, adolescents and young adults with von Willebrand disease. Results of a cohort study. Thromb Haemost 2011; 105:597-604

82 Berntorp E, Petrini P: Long-term prophylaxis in von Willebrand disease. Blood Coagul Fibrinolysis 2005;16(suppl 1):S23-S26.

83 Lethagen S: Clinical experience of prophylactic treatment in von Willebrand disease. Thromb Res 2006;118(suppl 1):S9-S11.

84 Federici AB: Highly purified VWF/FVIII concentrates in the treatment and prophylaxis of von Willebrand disease: the PRO. WILL Study. Haemophilia 2007;13(suppl 5):15-24.

85 Turecek PL, Mitterer A, Matthiessen HP, Gritsch H, Varadi K, Siekmann J, Schnecker K, Plaimauer B, Kaliwoda M, Purtscher M, Woehrer W, Mundt W, Muchitsch EM, Suiter T, Ewenstein B, Ehrlich HJ, Schwarz HP: Development of a plasma- and albumin-free recombinant von Willebrand factor. Hamostaseologie 2009;29(suppl 1):S32-S38. 
86 Suiter T, Laffan M, Mannucci PM, Kempton CL, Romond EH, Shapiro AD, Birschmann I, Gill JC, Ragni MV, Turecek P, Ewenstein BM, BioScience VSTB: Recombinant $\mathrm{Hu}-$ man Von Willebrand Factor (rhVWF): firstin-human study evaluating pharmacokinetics, demonstrating safety and tolerability in type 3 von Willebrand disease. ASH Annual Meeting Abstracts 2010;116:237.

87 Ragni MV, Jankowitz RC, Chapman HL, Merricks EP, Kloos MT, Dillow AM, Nichols TC: A phase II prospective open-label escalating dose trial of recombinant interleukin-11 in mild von Willebrand disease. Haemophilia 2008;14:968-977.

-88 Ragni MV, Jankowitz RC, Jaworski K, Merricks EP, Kloos MT, Nichols TC: Phase II prospective open-label trial of recombinant interleukin-11 in women with mild von Willebrand disease and refractory menorrhagia. Thromb Haemost 2011;106:641-645.

-89 De Meyer SF, Deckmyn H, Vanhoorelbeke K: von Willebrand factor to the rescue. Blood 2009;113:5049-5057.

90 Rivard GE, Aledort L: Efficacy of factor VIII/ von Willebrand factor concentrate Alphanate in preventing excessive bleeding during surgery in subjects with von Willebrand disease. Haemophilia 2008;14:271-275.

\$1 Hernandez-Navarro F, Quintana M, Jimenez-Yuste V, Alvarez MT, Fernandez-Morata $\mathrm{R}$ : Clinical efficacy in bleeding and surgery in von Willebrand patients treated with Fanhdi, a highly purified, doubly inactivated FVIII/VWF concentrate. Haemophilia 2008;14:963-967.
92 Coppola A, Cimino E, Conca P, De Simone C, Tufano A, Tarantino G, Cerbone AM, Minno G: Long-term prophylaxis with intermediate-purity factor VIII concentrate (Haemate $\mathrm{P}$ ) in a patient with type 3 von Willebrand disease and recurrent gastrointestinal bleeding. Haemophilia 2006;12:90-94.

93 Michiels JJ, Berneman ZN, van der Planken M, Schroyens W, Budde U, van Vliet $\mathrm{HH}$ Bleeding prophylaxis for major surgery in patients with type 2 von Willebrand disease with an intermediate purity factor VIII-von Willebrand factor concentrate (Haemate-P). Blood Coagul Fibrinol 2004;15:323-330.

94 Lubetsky A, Schulman S, Varon D, Martinowitz U, Kenet G, Gitel S, Inbal A: Safety and efficacy of continuous infusion of a combined factor VIII-von Willebrand factor (VWF) concentrate (Haemate-P) in patients with von Willebrand disease. Thromb Haemost 1999;81:229-233.

95 Kessler CM, Friedman K, Schwartz BA, Gill JC, Powell JS: The pharmacokinetic diversity of two von Willebrand factor (VWF)/ factor VIII (FVIII) concentrates in subjects with congenital von Willebrand disease. Results from a prospective, randomised crossover study. Thromb Haemost 2011;106:279-288.
96 Auerswald G, Eberspacher B, Engl W, Guthner C, Koksch M, Kreuz W, Nimtz A, Pindur G, Scheel H, Schreiber JD, Siekmann J, Turecek PL, Wolf HH: Successful treatment of patients with von Willebrand disease using a high-purity double-virus inactivated factor VIII/von Willebrand factor concentrate (Immunate). Semin Thromb Hemost 2002;28:203-214.

-97 Ver Elst KM, van Vliet HD, KappersKlunne MC, Leebeek FW: In vitro studies, pharmacokinetic studies and clinical use of a high purity double virus inactivated FVIII/VWF concentrate (Immunate) in the treatment of von Willebrand disease. Thromb Haemost 2004;92:67-74.

98 Viswabandya A, Mathews V, George B, Nair SC, Baidya S, Mammen JJ, Chandy M, Srivastava A: Successful surgical haemostasis in patients with von Willebrand disease with Koate DVI. Haemophilia 2008; 14: 763-767.

99 Lubetsky A, Martinowitz U, Luboshitz J, Kenet G, Keller N, Tamarin I, Inbal A: Efficacy and safety of a factor VIII-von Willebrand factor concentrate 8Y: stability, bacteriological safety, pharmacokinetic analysis and clinical experience. Haemophilia 2002;8:622-628.

100 Cumming AM, Fildes S, Cumming IR, Wensley RT, Redding OM, Burn AM: Clinical and laboratory evaluation of National Health Service factor VIII concentrate (8Y) for the treatment of von Willebrand's disease. Br J Haematol 1990;75:234-239. 